\title{
THE ANALYSIS OF PASSENGERS' FLUCTUATIONS DURING THE WEEKDAYS ON THE LINES SERVICED BY INTER-MUNICIPALITY CAR COMMUNICATION
}

\begin{abstract}
A company which provides services in the field of collective passenger transport must ensure that its offer is attractive to potential customers and also economically sound. This requires, inter alia, a competitive fare and the adaptation of the timetable and the fleet in use to the needs of the residents transport timetable. This will be possible only after a precise diagnosis of fluctuations in the stream of passengers. The paper presents the results of studies aimed at determining how to shape the daily fluctuations in the stream of passengers during the week and whether on different lines and in different time periods they are similar, i.e. if one can speak of the existence of a common pattern (profile). The analysis was based on the data from the period from July 2010 to March 2011, with the separately examined periods of winter and summer holidays. There were analyzed a number of selected lines connecting the suburban municipality of Rzeszów. The public transport services on these lines are provided by Inter-Municipality Car Communication (IMCC).
\end{abstract}

\section{INTRODUCTION}

The need for communication, which is defined as "a desire, a need or a request of individuals or specific communities on the process of movement from one place to another," is the primary source of demand for public transport services (see [6], s. 14).

The most common classification divides transportation needs because of the destination, which is the main determinant of the frequency, time of travel, and the choice of transport. Communication needs from the point of view of the destination can be divided generally into: professional, living, recreation and others. A more detailed list of objectives includes work, school, home, shopping, professional and business affairs, personal affairs, social affairs and recreation. Transport needs arising from professional objectives are highly concentrated in time, the stability of the spatial distribution and the highest frequency and regularity of occurrence. Transport needs related to the objectives of the existence and other recreational activities are characterized by significantly less regularity, large variations in space and lesser intensity (see [2], s. 27-28).

Specific needs of transport are characteristic for municipalities neighboring big cities. Villages located in such municipalities are increasingly of the urban nature of the settlements. A large part of the population of the village works, learns and cares of other things in the city. Thus, suburban municipalities are part of the larger cities. For the

\footnotetext{
${ }^{1}$ Mirosław Śmieszek, DSc, PhD, Eng., Department of Quantitative Methods, The Faculty of Management, Rzeszow University of Technology, Rzeszow.

${ }^{2}$ Mirosław Liana, PhD, Department of Quantitative Methods, The Faculty of Management, Rzeszow University of Technology, Rzeszow.
} 
residents of these communities the dominant travel relationships are villages (residential) municipalities - city. The nature of life and the spatial management cause even stronger demand for the construction of transport offer in relation to the big city. Therefore, adapting to the movements of this nature offers of a public communication line is of the shape of the beam moving in the radial direction of city (see [3], s. 23).

Municipal governments are responsible for the organization of public transport in cities. These tasks and competences have been transferred in the act as the direct responsibility of municipalities. In such an explicit form has not been assigned the responsibility for the organization of public transport supra-level of the municipalities. Taking care of the interests of the inhabitants of large cities, metropolitan regions, and municipalities in the metropolitan region of concentration, the local authorities are trying to make inter-municipality agreements on the joint organization of transport and financing of public transport (see [1], s. 2).

Public transport services are needed for both local residents, employers, schools and universities, local government, health, culture animators, as well as residents of metropolitan area. In replying to this demand, several communities centered around the city of Rzeszow signed an agreement under the name "Municipality Union of Podkarpackie Car Communication". On 1 April 2010 the organization started the intervehicle traffic. On 1 May 2010 it began a regular operation of 10 suburban lines, connecting the surrounding municipality of the city of Rzeszów. Currently, it provides transport services on 13 lines, of which 11 is used Rzeszow bus fleet, while the other two lines are operated by a private carrier. The current inter-communication diagram of InterMunicipality of Car Transport is shown in Figure 1.

Fig.1. Scheme of suburban routes operated by Inter-Municipality Car Communication.

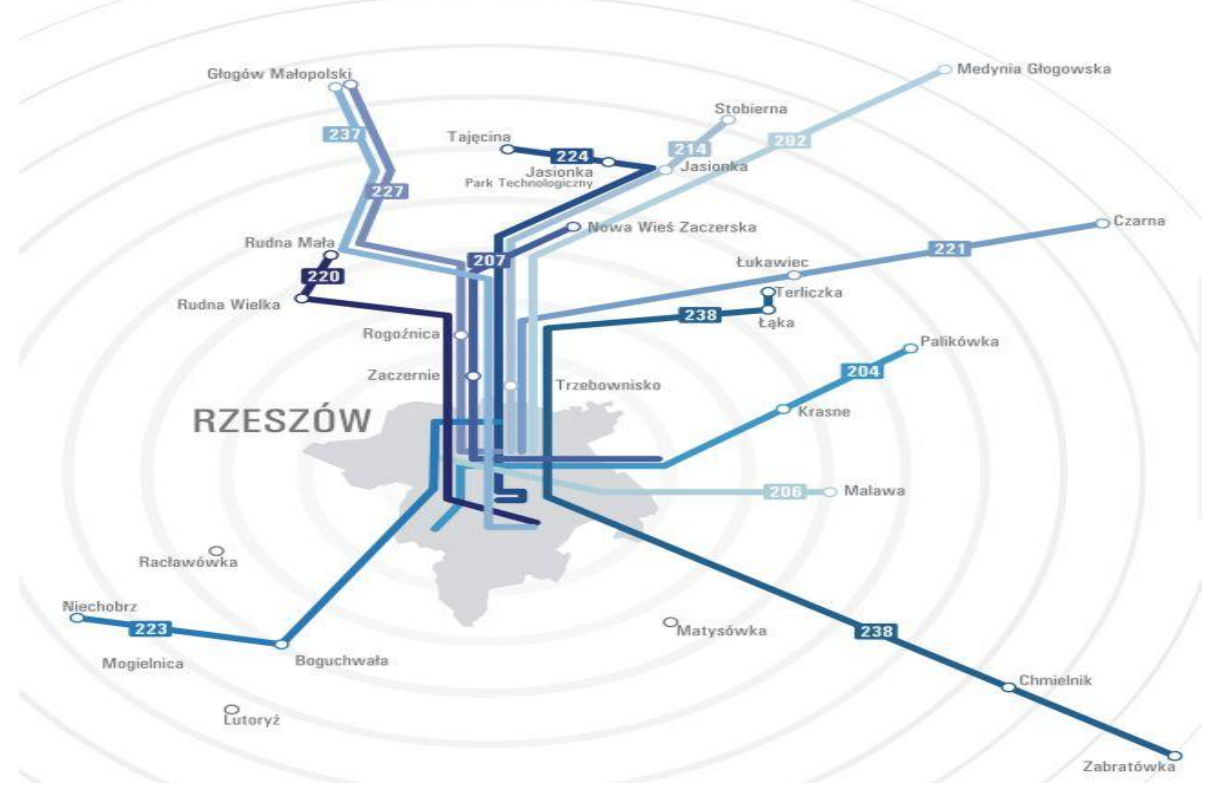

Source: http://www.zgpks.rzeszow.pl/?trasy-przejazdu.html (1 XI 2012). 
One of the features of communication needs within the urban areas is the unevenness of the occurrence, which manifests itself in fluctuations in demand for transport services both in time and in space.

Time irregularity of communication needs manifests itself in the form of hourly fluctuations throughout the day, and daily during the week, month or year. Hourly fluctuations, resulting from the organization of work and life of the population, are the cause of occurring during the peak traffic day of commuting and return to/from work and schools/universities (see [2], s. 28).

Shipping need will be transformed into demand only if they are made suitable conditions in the form of attractive transport by public transport. It consists of: the timetable, tariff offer, fleet, security and information (see [2], s. 27). It is also important an economic dimension of the activities of public transport. Providing transport services should be a profitable activity. This requires at least an offset of the cost by revenues. Only a precise identification of variations in the stream of passengers allows to create an attractive and profitable transport offer. It allows to adjust the timetable for the size of the fleet and the reported transport needs. This, in turn has an impact on the competitive fare structure.

In the papers $[4,5]$ it was shown how hourly fluctuations shape throughout the day on the lines served by inter-vehicle traffic. This paper presents the results of studies aimed at determining how to shape the daily fluctuations in the stream of passengers during the week in a few selected lines operated by Inter-Municipality Car Communication. It was examined whether the different lines and in different periods of time within the daily fluctuations of the week they are similar, i.e. if one can speak of the existence of a common pattern (profile). Calculations were performer by using Excel and Statistica.

\section{RESEARCH DESCRIPTION}

The used in the research data on the actual turnout of passengers each day was collected by IMCC by installing the system in all the buses running to allow electronic registration of the current passengers.

The paper presents the results of the six lines, for which the complete data was available from the period of time. Each of these lines combines Rzeszów with the suburban municipality. These lines are marked as: L1, L2, L3, L4, L5, L6.

The analysis was based on the data from the period from July 2010 to March 2011. Although the company has been operating since May 2010, it was omitted in the analysis - due to their specific nature - starting the first two months - May and June 2010.

There were examined three periods of operation. Separate calculations were performed for vacation periods: summer (July and August 2010) and winter (17-31 January 2011). Other intervals were called normal work period. Because of the way the calculations were carried out, there were included in the study only weeks wholly contained in one of the aforementioned periods. In addition, there were missed weeks in which at least one day was a public holiday. Each of these weeks requires separate study due to the occurrence of so-called "Long weekends".

The aim of the studies was to isolate fluctuations in the weekly cycle. The actual data during the period was also characterized by volatility and trend due to certain seasonal fluctuations. The scale of this variability was different on different lines. To eliminate 
these interfering fluctuations the output data was converted in the following manner. Separately for each line and each week:

(1) calculated the average of the actual attendance on weekdays (Monday to Friday); in the following part of the paper there will be used the name of the average of daily attendance;

(2) divided the attendance of each day by the average of daily attendance; such ratios, hereinafter referred to relative attendances were subjected to further statistical treatment of the material, allowing to make comparisons between different lines.

\section{DATA ANALYSIS}

At the outset there were analyzed weeks during the regular week. In Figure 2 it was illustrated how developed the number of passengers, namely the relative frequencies on one of the lines in four consecutive weeks. It is noticeable a repeated weekly schedule. A similar pattern occurs on the other examined lines.

Fig. 2. Relative attendance on L1 line in the selected 4 weeks.

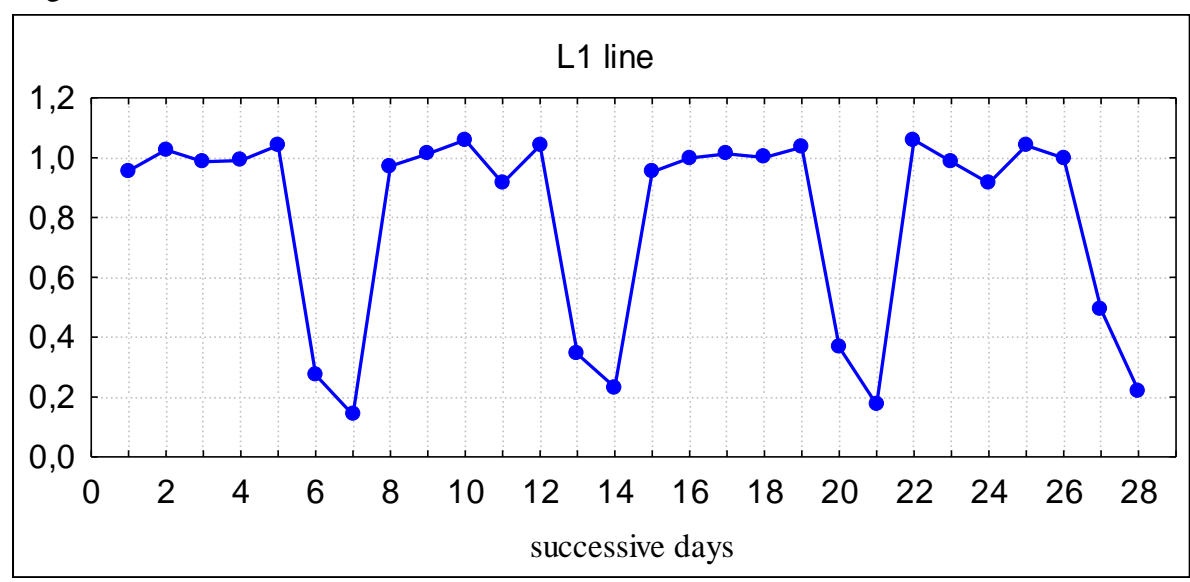

Source: own study.

Table 1. Average relative attendance in the regular period.

\begin{tabular}{|l|c|c|c|c|c|c|c|}
\hline Day of the week & L1 & L2 & L3 & L4 & L5 & L6 & $\begin{array}{c}\text { Average for } \\
\text { all the lines }\end{array}$ \\
\hline Monday & 0,97 & 0,96 & 0,99 & 0,95 & 0,97 & 1,03 & 0,98 \\
\hline Tuesday & 1,01 & 1,00 & 1,01 & 1,04 & 1,01 & 1,02 & 1,02 \\
\hline Wednesday & 0,98 & 1,00 & 0,99 & 0,99 & 1,01 & 0,99 & 0,99 \\
\hline Thursday & 0,99 & 0,99 & 0,97 & 0,99 & 0,98 & 0,97 & 0,98 \\
\hline Friday & 1,04 & 1,04 & 1,04 & 1,02 & 1,03 & 0,99 & 1,03 \\
\hline Saturday & 0,42 & 0,35 & 0,30 & 0,39 & 0,28 & 0,32 & 0,34 \\
\hline Sunday & 0,20 & 0,20 & 0,19 & 0,30 & 0,17 & 0,18 & 0,21 \\
\hline
\end{tabular}

Source: own study. 
To clean the data from random fluctuations there was calculated the average attendance for each day of the week on all lines. This average is shown in Table 1.

The analysis of the results collected in Table 1 leads to several conclusions.

Conclusion 1. On all lines on weekdays the average attendance of passengers is very stable and does not show clear deviations from the everyday average (ranging between $95 \%$ and $104 \%)$.

Conclusion 2. On all lines the average attendance of passengers is less than the average everyday on Thursday, and if to skip the line L6 - it is also on Mondays.

Conclusion 3. Similarly, it can be seen that in all lines the average attendance of passengers is greater than the average everyday on Tuesday, and if to skip the line L6 also on Fridays.

Conclusion 4. On all lines the average attendance of passengers on Saturdays is much lower than on weekdays, and on average it is $34 \%$ of the average everyday (depending on the line varies from $28 \%$ to $42 \%$ ).

Conclusion 5. The lowest average attendance of passengers on all lines is on Sundays. In five of the surveyed lines the average Sunday attendance ranges from $17 \%$ to $20 \%$ of the average every day. Only in the case of the line L4 is $30 \%$, which seems to be some kind of anomaly.

The average weekly cycle fluctuations in the relative frequency is shown in Figure 3.

Fig. 3. The average relative attendance in all the lines in the regular period.

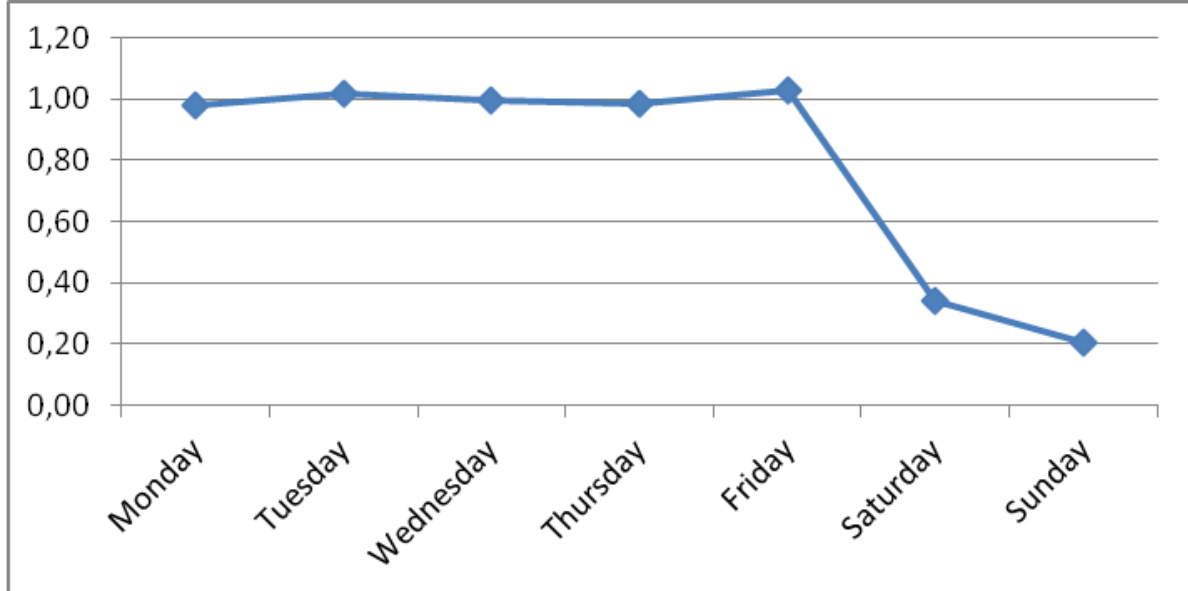

Source: own study.

To assess the frequency variation in the researched period the variation coefficients ${ }^{3}$ were calculated for each day of the week. Collected in Table 2 results allow to draw further conclusions.

Conclusion 6. The relative differences of attendance on weekdays is significantly lower than on Saturdays and Sundays. This is mainly due to the much higher average attendance on weekdays.

${ }^{3}$ Variation coefficient $=$ standard deviation $/$ mean value 
Conclusion 7. Regardless of the line, weekday attendance is characterized by relatively small fluctuations around the everyday mean average (not exceeding 8.4\%). None of those days does not stand out against the rest.

Conclusion 8. On Saturdays and Sundays the average deviations from the average attendance is at a similar level, and depending on the line (except L4) oscillate in the range of $11.4 \%$ to $17 \%$. Line L4, especially on Sundays, apart from the relatively higher average attendance than the other lines is also characterized by higher volatility rate of $24.6 \%$.

Table 2. Variation coefficient of attendance in the researched period.

\begin{tabular}{|l|c|c|c|c|c|c|}
\hline Day of the week & L1 & L2 & L3 & L4 & L5 & L6 \\
\hline Monday & 0,059 & 0,067 & 0,057 & 0,084 & 0,047 & 0,035 \\
\hline Tuesday & 0,031 & 0,045 & 0,044 & 0,074 & 0,038 & 0,039 \\
\hline Wednesday & 0,041 & 0,041 & 0,041 & 0,053 & 0,043 & 0,047 \\
\hline Thursday & 0,053 & 0,041 & 0,057 & 0,045 & 0,062 & 0,062 \\
\hline Friday & 0,033 & 0,046 & 0,045 & 0,066 & 0,038 & 0,037 \\
\hline Saturday & 0,119 & 0,168 & 0,158 & 0,173 & 0,146 & 0,158 \\
\hline Sunday & 0,133 & 0,170 & 0,151 & 0,246 & 0,114 & 0,149 \\
\hline
\end{tabular}

Source: own study

The same calculations were carried out separately for periods of winter and summer holidays. Because of the similarity of the detailed results to those presented for the normal period, in table 3 there were shown only the mean values (in relation to the lines) of selected parameters describing the relative attendance of different periods.

In the periods of holidays there is also outlined in the conclusion 1 lack of correlation between the weekdays and the average attendance on all the lines. However, shown in Table 3 differences will be written in the form of subsequent conclusions.

Table 3. The average for all lines of statistical parameters defining the relative attendance in different periods.

\begin{tabular}{|c|c|c|c|c|c|c|c|c|c|}
\hline \multirow{3}{*}{$\begin{array}{c}\text { Day } \\
\text { of } \\
\text { the week }\end{array}$} & \multicolumn{3}{|c|}{ Average } & \multicolumn{3}{|c|}{ Standard deviation } & \multicolumn{3}{|c|}{ Variation coefficient } \\
\hline & \multirow{2}{*}{$\begin{array}{l}\text { normal } \\
\text { period }\end{array}$} & \multicolumn{2}{|c|}{ holidays } & \multirow{2}{*}{$\begin{array}{l}\text { normal } \\
\text { period }\end{array}$} & \multicolumn{2}{|c|}{ holidays } & \multirow{2}{*}{$\begin{array}{c}\text { normal } \\
\text { period }\end{array}$} & \multicolumn{2}{|c|}{ holidays } \\
\hline & & summer & winter & & summer & winter & & summer & winter \\
\hline Monday & 0,979 & 0,963 & 0,978 & 0,057 & 0,055 & 0,026 & 0,058 & 0,056 & 0,027 \\
\hline Tuesday & 1,016 & 1,000 & 1,035 & 0,046 & 0,065 & 0,039 & 0,045 & 0,065 & 0,038 \\
\hline Wednesday & 0,994 & 1,024 & 1,011 & 0,044 & 0,060 & 0,034 & 0,044 & 0,058 & 0,033 \\
\hline Thursday & 0,983 & 0,988 & 1,001 & 0,052 & 0,063 & 0,065 & 0,053 & 0,064 & 0,066 \\
\hline Friday & 1,027 & 1,026 & 0,975 & 0,045 & 0,055 & 0,078 & 0,044 & 0,054 & 0,080 \\
\hline Saturday & 0,342 & 0,385 & 0,392 & 0,052 & 0,082 & 0,040 & 0,154 & 0,214 & 0,116 \\
\hline Sunday & 0,206 & 0,288 & 0,252 & 0,035 & 0,058 & 0,031 & 0,161 & 0,204 & 0,136 \\
\hline
\end{tabular}

Source: own study. 
Conclusion 9. The average attendance in the vacation periods on Saturdays is still substantially lower than on weekdays, and is approximately $39 \%$ of the average everyday (for each line varies from $31 \%$ to $54 \%$ ). But it is about $5 \%$ higher than in a normal period, which is mainly due to the weekday lower average during the holidays.

Conclusion 10. In a similar way the average attendance shapes on Sundays. In the vacation period it is by a few percent higher than during a normal period, but still much lower than on weekdays. In periods of holidays there is more drop in attendance on weekdays (working) than on Saturdays and Sundays, hence the relative percentage increase.

Conclusion 11. In all three researched periods the absolute frequency fluctuations expressed by the standard deviation did not differ significantly from each other. However, coefficients of variation indicate a higher than on weekdays relative fluctuations on Saturdays and Sundays. In comparison with the usual period during the summer holidays there are more relative fluctuations (about 20\%), while during the winter - a bit lower $(11-14 \%)$.

\section{CONCLUSIONS}

Studies have confirmed that the communication needs of residents of communities neighbouring urban agglomerations are characterized by irregularity of the time, which manifests itself in the form of daily fluctuations within a week.

The differences in attendance on weekdays any week in all tested lines were minor and did not show any regularity. However, the attendance on Saturdays and Sundays was significantly smaller. Apart from holidays and vacation periods, the attendance on Saturday was on average $66 \%$ less than at a weekday and on Sunday by about $80 \%$ smaller. One will notice that the attendance on Saturdays and Sundays varies considerably.

The differences in the periods of vacation days between the weekdays and Saturdays and Sundays were smaller. This can be explained by the fact that during holidays is a greater reduction in demand for transportation on weekdays than at weekends (no need to travel to school and a reduced need to travel to work - the holiday period). On Saturday the attendance was lower by about $61 \%$ than on weekdays, and on Sundays - by about $70 \%$ in summer and $75 \%$ in winter. The latter difference may be explained by the fact that in large centers during the summer on Sundays there are just a lot of cultural and entertainment events that attract the inhabitants of the surrounding municipalities. This creates an additional demand for transport on the routes suburban municipality Rzeszow.

It can be concluded that daily fluctuations in the frequency of the week were not significantly different for the various lines, and varied depending on the period. Adapting its shipping offer to changing demand, it is reasonable to create separate schedules for weekdays, Saturdays and Sundays, as well as for periods of winter and summer holidays. The difference between the number of passengers on weekdays and on Saturdays and Sundays are so large that in addition to other schedules will also require proper selection of the fleet. Only then courses on weekdays and weekends can be profitable. 


\section{REFERENCES}

[1] Bryniarska Z.: Rozwój obstugi komunikacyjnej mieszkańców w obszarze aglomeracyjnym miasta Krakowa, „Transport Miejski i Regionalny” 06/2010.

[2] Hebel K.: Potrzeby przewozowe jako determinanty popytu na ustugi transportu miejskiego, „Przegląd Komunikacyjny” 12/2007.

[3] Kruszyna M.: Komunikacja publiczna w gminach sasiadujacych $z$ dużymi miastami, „Transport Miejski i Regionalny” 10/2009.

[4] Liana M., Śmieszek M.: Analiza popytu na przewozy pasażerskie oferowane przez Międzygminna Komunikację Samochodowa, „Logistyka” 3/2012.

[5] Liana M., Śmieszek M.: System międzygminnej komunikacji samochodowej w województwie podkarpackim i jego uwarunkowania, „Logistyka” 13/2011.

[6] Pawlicka Z.: Przewozy pasażerskie, WKiє, Warszawa 1978.

[7] http://www.zgpks.rzeszow.pl/?trasy-przejazdu.html (1 XI 2012).

\section{ANALIZA WAHAŃ POTOKU PASAŻERÓW W CIĄGU TYGODNIA \\ NA LINIACH OBSLUGIWANYCH PRZEZ MIĘDZYGMINNĄ KOMUNIKACJĘ SAMOCHODOWĄ}

Przedsiębiorstwo, które świadczy usługi w zakresie zbiorowych przewozów pasażerskich musi zadbać o to, żeby jego oferta była atrakcyjna dla potencjalnych klientów i jednocześnie uzasadniona ekonomicznie. Wymaga to między innymi stworzenia konkurencyjnej oferty taryfowej oraz dostosowania do potrzeb przewozowych mieszkańców rozkładu jazdy i wykorzystywanego taboru. Będzie to możliwe jedynie po precyzyjnym rozpoznaniu wahań potoku pasażerów. $\mathrm{W}$ pracy przedstawiono wyniki badań, których celem było określenie, jak kształtują się wahania dobowe potoku pasażerów w ciagu tygodnia, czy na różnych liniach i w różnych okresach czasu są one podobne, czyli czy można mówić o istnieniu jednego wspólnego wzorca (profilu). Analizę przeprowadzono w oparciu o dane z okresu od lipca 2010 roku do marca 2011 roku, przy czym oddzielnie rozpatrzono okresy ferii letnich i zimowych. Analizie poddano kilka wybranych linii łączących gminy podmiejskie z Rzeszowem. Usługi transportu zbiorowego świadczy na tych liniach Międzygminna Komunikacja Samochodowa (MKS).

DOI: $10.7862 /$ rz.2012.zim.30 